\title{
Effect of phytoplankton cell size on transient- state nitrate and ammonium uptake kinetics
}

\author{
Willem Stolte and Roel Riegman
}

Author for correspondence: Willem Stolte. e-mail : wstolte@nioz.nl

Netherlands Institute for Sea Research, PO Box 59, 1790 AB Den Burg,

The Netherlands

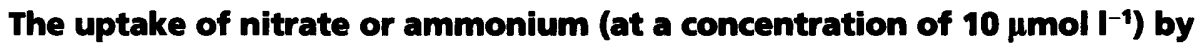
marine phytoplankton was studied in relation to cell size. Initial specific nitrate uptake rates by small $\left(35000 \mu \mathrm{m}^{3}\right)$ and large $\left(130000 \mu \mathrm{m}^{3}\right)$ cells of the diatom Ditylum brightwellii did not differ significantly. However, the larger cells maintained a high uptake rate for a longer time. Therefore, they accumulated nitrate in a higher biomass-specific pool than the smaller cells. In the dark, this effect was even more pronounced. Two smaller diatom species, Lauderia borealis $\left(7474 \mu \mathrm{m}^{3}\right)$ and Thalassiosira pseudonana $\left(98 \mu \mathrm{m}^{3}\right)$, had lower initial specific nitrate uptake rates and lower intracellular pools. Transientstate ammonium uptake did not result in accumulation of large intracellular pools of ammonium. Theoretically, and on the basis of the presented results, we stress the dualistic functional role of the vacuole. A large vacuole is an effective way for larger algal species to possess a minimum cell nutrient quota/cell surface ratio which is in the range of smaller species. Furthermore, by functioning as a storage reservoir it reduces inhibition of the uptake rate by cytoplasmic accumulated nutrients. The effect of the latter mechanism is that larger algal species are better at nitrate uptake under fluctuating conditions. These results imply that, in nitrogen-controlled marine systems, resource competition under fluctuating nutrient concentrations can only lead to a shift towards larger phytoplankton species if nitrate rather than ammonium is the main nitrogen source. From theoretical considerations it is argued that the maximum growth rate of algae is determined by nutrient assimilation properties rather than by photosynthetic capacity.
\end{abstract}

Keywords: phytoplankton size, nitrate, ammonium, uptake, storage

\section{INTRODUCTION}

Plankton populations in oligotrophic oceans differ in general from those in more eutrophic waters. In the oligotrophic oceans, small phytoplankton (prokaryotes and small eukaryotes) is dominant. Primary production is mostly based on ammonium, and the algae are grazed by protozooplankton. In the more eutrophic areas, larger species are generally the dominant primary producers (Owens et al., 1990). These large algae are grazed by mesozooplankton. Here, much of the production is based on nitrate, not originating from the photic zone (new production). Several alternative explanations for this difference in phytoplankton size distribution have been proposed. The high sinking rates of larger algae are thought to be a reason why they do not occur in stratified, oligotrophic oceans (Margalef, 1978). However, this alone would not explain their abundance in coastal, frequently mixed waters. Also, size-differential grazing is an im- portant factor in regulating the size distribution within natural phytoplankton assemblages (Riegman et al., 1993). In this concept, biomass accumulation by large algae acts as a nutrient overflow mechanism. The biomass distribution of different size classes of algae is explained by this concept as a function of total nutrient availability. However, the size-related productivity of phytoplankton is less well explained. Furthermore, the availability of ammonium in oceanic waters versus nitrate in coastal waters is believed to influence phytoplankton size. Ammonium would be better taken up by small algae, while nitrate would be used more by the larger phytoplankton. This hypothesis is consistent with many field data (e.g. Probyn, 1985; Owens et al., 1991), although the conclusion from these observations should be handled with care, because heterotrophic bacteria could play a significant role in ammonium uptake. Also, no physiological mechanism has so far been proposed that would sufficiently explain the size-differential nitrate preference. In 
some cases, a complicating factor could be the iron availability, which is hypothesized to limit the use of nitrate, especially for the larger phytoplankton in the ironpoor regions of the oceans (Price et al., 1991).

In this paper we document and discuss the influence of variability in nutrient supply. The effect of cell size within one species of diatom (Ditylum brightwellii) on uptake of nitrate and ammonium was first studied. In this way, we could discriminate between the effect of size and the effect of taxonomic differences. The effect of absence of light on transient-state nitrate uptake was then determined, to see if the size-dependence of nitrate uptake was more pronounced under limiting energy and reductant supply. Finally, nitrate and ammonium uptake and storage by two smaller species of diatoms (Lauderia borealis and Thalassiosira pseudonana) was examined, to see if the differences found within one species are reflected in other species of different size.

\section{THEORETICAL BACKGROUND}

Small algae are believed to have a higher specific growth rate at low nutrient concentrations than larger algae, because of their higher surface-to-volume ratio (Banse, 1976). We will show that in marine systems, where primary production is often nitrogen controlled, there is little theoretical support for this postulate. To elaborate this we will derive equations showing the relationship of surface-mediated uptake processes to size. Because marine systems are mainly nitrogen controlled, we will express biomass and uptake rates in terms of nitrogen. In order to relate population growth rate to cellular characteristics, we assume that all cells in a population have the same shape and size, which is not influenced by cell growth and division. It is obvious that this simplification is more appropriate for non-synchronously than for synchronously dividing algae.

Nutrient uptake per cell $(V)$ is described by MichaelisMenten kinetics:

$V=\frac{V_{\max } \cdot S^{\prime}}{K_{\mathrm{m}}+S^{\prime}}$

There is no physiological reason to assume that the halfsaturation constant for nutrient uptake $\left(K_{\mathrm{m}}\right)$ is dependent on cell size. For this reason, we will assume that $K_{\mathrm{m}}$ is constant. The substrate concentration at the cell surface $\left(S^{\prime}\right)$ is lower than the concentration in the bulk medium $(S)$ because nutrients have to diffuse to the cell along a concentration gradient. We will first assume that transport towards the cell by diffusion $\gg$ cellular uptake rate. In that case $S^{\prime} \approx S$.

\section{Steady-state population growth}

If algae are growing with a constant nitrogen supply, uptake rate per cell and the specific population growth rate $\left(\mu\right.$ in $\left.\mathrm{h}^{-1}\right)$ are balanced:

$\mu=\frac{V}{Q}$
The uptake rate per cell ( $V$ in $\mu \mathrm{mol}$ nitrogen per cell $\mathrm{h}^{-1}$ ) as well as the cell nutrient quota $(Q$ in $\mu \mathrm{mol}$ nitrogen per cell) are size dependent. If we can relate both these parameters to cell volume then we can describe the size dependence of phytoplankton growth. We here assume that the transporter density in the plasmalemma, and the characteristics of these carriers, are independent of cell size. In that case, $V_{\max }$ is linearly related to the cell membrane area. If we assume a constant cell shape, we can state that the maximum uptake rate is related to cell volume $\left(W\right.$ in $\left.\mu \mathrm{m}^{3}\right)$ in the following way:

$V_{\max }=\alpha \cdot W^{2 / 3}$

$\alpha$ depends on the density and the maximum activity of transporters in the plasmalemma and also contains a shape factor. In order to relate the specific growth rate to cell size, a description of the size dependence of $Q$ is necessary. This relationship has been determined empirically by several authors (see below). $Q$ also varies with growth rate, so it would not be sufficient to use a simple relationship. Here, we will only consider two extreme cases.

(1) Under severely nutrient-limited conditions, algae are growing with a growth rate $\ll \mu_{\max }$. In that case, the cell quota for nitrogen approaches the subsistence quota $\left(Q_{\text {min }}\right)$, which is related to cell volume $(W)$ :

$Q_{\min }=a . W^{b}$

where $b=0 \cdot 71 \approx 2 / 3$ (Shuter, 1978). In this equation, $a$ represents a constant that is dependent on the units in which $Q_{\min }$ and $W$ are expressed. The value of $b$ is similar for the relationship of the phosphorus quota with cell volume $(b=0 \cdot 70$, Smith \& Kalff, 1982; $b=0 \cdot 71$, Grover, 1989a). Substitution of eq. (1) and eq. (4) in eq. (2) yields:

$\mu=\frac{\alpha \cdot f \cdot W^{2 / 3}}{a \cdot W^{2 / 3}}$

or

$\mu=\frac{\alpha \cdot f}{a}$

where $f=S .\left(K_{\mathrm{m}}+S\right)^{-1}$ (unitless). It is clear from eq. (5) that the specific growth rate of algae becomes independent of cell size in the limiting case that $\mu=0$.

(2) Under non-limiting conditions the population growth rate is defined as $\mu_{\max }$. In that case, cell quota has a maximum value $\left(Q_{\max }\right)$. Although in this case nitrogen assimilation does not have to be the limiting factor, we here make calculations assuming that nitrogen uptake is controlling the population growth rate. We are aware that this step is purely hypothetical, but as we will show later, the results are in agreement with experimental data. For nitrogen, no general empirical relationship of $Q_{\max }$ with algal cell size has been described. Because the slopes of the size relationship of $Q_{\mathrm{min}}$ for nitrogen and phosphorus were identical, we assume that this is also valid for $Q_{\max }$. Therefore we use a relationship of phosphorus quota with cell size:

$Q_{\max }=a^{\prime} \cdot W^{b^{\prime}}$ 
where $b^{\prime}=0.77$ (Grover, 1989a). Substituting eq. (3) and eq. (6) in eq. (2) yields:

$\mu_{\max }=\frac{\alpha \cdot W^{2 / 3}}{a^{\prime} \cdot W^{0 \cdot 77}}$

or

$\mu_{\max }=\frac{\alpha}{a^{\prime}} \cdot W^{-0 \cdot 10}$

Blasco et al. (1982) found a nitrogen quota related to cell volume with five species of diatoms under non-limiting conditions and found that $b^{\prime}=0 \cdot 87$. Equation (7) would then become:

$\mu_{\max }=\frac{\alpha}{a^{\prime}} \cdot W^{-0 \cdot 20}$

So, according to equations (7) and (7a) the maximum specific growth rate of algae would be negatively correlated with cell size. Considering the range between $\mu=0$ and $\mu=\mu_{\max }$, it can be concluded that under severely limiting conditions the size-differential specific growth rate $(\mu)$ of algae becomes less pronounced than under moderate limitation.

\section{Diffusion limitation}

The implication of equation (5) is that size-related nutrient uptake and biomass do not result in differential growth rates under severely nutrient-limiting conditions. However, with decreasing nutrient concentrations in the surrounding medium, diffusion limitation of nutrient uptake becomes more important. Experimental data on marine phytoplankton that confirm the actual importance of diffusion limitation are lacking, but theoretically, large cells suffer more from diffusion limitation than smaller ones (Munk \& Riley, 1952; Pasciak \& Gavis, 1974). Also, field data confirm the absence of large immobile cells in nutrient-depleted, stagnant waters. Besides other factors, such as size-differential sedimentation losses, diffusion limitation of nutrient uptake might play a role in determining the size spectrum of a phytoplankton population when nutrient concentrations are extremely low.

\section{Fluctuating external nutrient concentrations}

It is obvious that in aquatic ecosystems constant nutrient supply rates do not occur. Under certain circumstances nitrogen-limited algae are faced with a relatively high nutrient concentration. This situation can occur in coastal areas where freshwater runoff from land can account for variations in nutrient concentrations, but also at the bottom of the photic zone where nutrient-rich water enters the (nutrient-limited) photic zone irregularly. The cell quota of algae growing under considerable $\mathrm{N}$-stress $\left(\mu \leqslant 0.25 \mu_{\max }\right)$ approaches the subsistence quota $\left(Q_{\min }\right)$. If the nutrient concentration is temporarily elevated to levels that are saturating for the uptake system, the biomass-specific uptake rate $\left(V_{r, \max }\right)$ then becomes:

$V_{\mathrm{r}, \max }=\frac{V_{\max }}{Q_{\min }}$
Substitution of equations (3) and (4) yields:

$V_{\mathrm{r}, \max }=\frac{\alpha \cdot W^{2 / 3}}{a \cdot W^{2 / 3}}=\frac{\alpha}{a}$

Apparently, there is no size dependence of biomassspecific uptake rate under these conditions.

\section{Storage}

Transport across the cell membrane is probably the ratelimiting step in transient-state ammonium assimilation. Once in the cytoplasm, ammonium is rapidly assimilated by the GS/GOGAT or GDH enzyme system. Indirect evidence for this lies in the fact that intracellular ammonium pools are never very high (Dortch, 1982). Therefore, the uptake of ammonium is sufficiently described by equation (8). However, uptake of relatively high concentrations of nitrate by nitrogen-stressed phytoplankton requires storage of nitrate, because assimilation is believed to be limited by the reduction of nitrate to nitrite (Dortch, 1982). Both uptake and reduction of nitrate require energy, while reduction of nitrite to ammonium also requires reduced ferredoxin. Under low photon flux densities, competition for energy and reductive equivalents might occur between the nitrate uptake system and the nitrate and nitrite reductases. In that case, complex interactions between uptake and reduction of nitrate can be expected. The dissolved nitrate accumulates in the cytoplasm and is most probably actively transported to the vacuole, where the concentration can be higher than in the cytoplasm (Miller \& Zhen, 1991). The storage capacity of a cell is therefore dependent on the vacuole volume. If we assume that the vacuole itself does not contribute to the nitrogen biomass of a cell and that biomass always occupies a certain cytoplasm volume, then we can state that:

$W_{\mathrm{vac}}=W-\frac{Q_{\min }}{s}$

where $s=$ nitrogen (cytoplasm volume) ${ }^{-1}$ in $\mu \mathrm{mol} \mu \mathrm{m}^{-3}$. Biomass-specific storage capacity then becomes:

$\frac{W_{\mathrm{vac}}}{Q_{\min }}=\frac{W-\frac{Q_{\min }}{s}}{Q_{\min }}$

after substitution of eq. (4):

$\frac{W_{\mathrm{vac}}}{Q_{\min }}=\frac{W^{0 \cdot 29}}{a}-\frac{1}{s}$

An implication of eq. (10) is that, with the chosen units, the vacuole volume becomes negative if the cell volume $<1 \mu \mathrm{m}^{3}$. This is no real problem because for a spherical cell this would correspond to a radius of $0.62 \mu \mathrm{m}$, which is about the minimum size of eukaryotic photolithotrophs (Raven, 1986). Equation (10) shows that the specific storage capacity in the vacuole increases with cell size in 
case of severe nitrogen limitation. Indeed, larger algae have relatively larger vacuoles (Raven, 1984). Our hypothesis is that smaller cells can maintain a high uptake rate for a shorter period of time than larger cells. There are two possible mechanisms by which this could be achieved: (i) the intracellular nitrate concentration increases relatively faster in small cells, causing inhibition of nitrate uptake by increasing the gradient over the cell membrane; (ii) accumulation of a metabolite (ammonium or an amino acid) inhibits nitrate uptake - this effect will be stronger in small cells.

\section{METHODS}

Growth conditions. For all experiments, the growth medium was based on sterile aged North Sea water which contained less than $0.3 \mu \mathrm{mol}$ total dissolved inorganic nitrogen $1^{-1}$. Prior to sterilization $\left(20 \mathrm{~min}\right.$ at $\left.121^{\circ} \mathrm{C}\right), 2 \mathrm{ml} \mathrm{1.2} \mathrm{M} \mathrm{HCl} \mathrm{l}^{-1}$ was added to prevent precipitation of calcium and magnesium salts during autoclaving. After sterilization, sterile nutrient solutions were added aseptically (final concentrations): $\mathrm{HCO}_{3}^{-}\left(2666 \mu \mathrm{mol} \mathrm{l}^{-1}\right)$, $\mathrm{NaH}_{2} \mathrm{PO}_{4}\left(25 \mu \mathrm{mol} \mathrm{l}^{-1}\right), \mathrm{NaSiO}_{3}\left(150 \mu \mathrm{mol} \mathrm{l}^{-1}\right)$, trace metals and vitamins according to Veldhuis \& Admiraal (1987). Nitrate or ammonium was added to the growth medium to a final concentration of $20 \mu \mathrm{mol} \mathrm{l}^{-1}$. Light was supplied by TL tubes (colour $54,175 \mu \mathrm{mol} \mathrm{m}^{-2} \mathrm{~s}^{-1}$ ) and a light/dark cycle of $16 / 8 \mathrm{~h}$. The cultures were diluted every $3 \mathrm{~d}$ by replacing half of the culture with fresh medium containing either $\mathrm{NO}_{3}^{-}$or $\mathrm{NH}_{4}^{+}$(final concentration $10 \mu \mathrm{mol} \mathrm{l}^{-1}$ ), which typically became exhausted in $10-25 \mathrm{~h}$. Changes in biomass were monitored by measuring the optical density at $750 \mathrm{~nm}$ just before each dilution. After 5-10 dilutions, optical density at the end of two succeeding $3 \mathrm{~d}$ periods was constant. At that time, the algae were considered to be physiologically adapted to the fluctuating nutrient regime and samples for nutrients and cell numbers were collected.

Algal cultures. From an axenic culture of Ditylum brightwellii (Bigelow no. 358), individual cells were isolated with a micropipette in a sterilized laminar-flow hood. These cells were cultured in the growth medium described above. After 2 weeks, the cultures were checked for bacteria and cell size. Two axenic cultures with the largest difference in cell size were chosen for the experiment. The cultures were checked for bacteria every $3 \mathrm{~d}$ using the method of Hobbie et al. (1977) and were axenic during the whole experiment. Lauderia borealis, isolated from the Dutch coastal North Sea and Thalassiosira pseudonana (Bigelow no. 1335) were non-axenic cultures. However, bacteria were regularly counted, and their biovolume never contributed more than $0.1 \%$ of algal biovolume.

Chemical and biological analyses. Samples for determination of nutrient concentrations in the medium were taken by pipetting $4 \mathrm{ml}$ supernatant after centrifuging $5 \mathrm{ml}$ of the culture for $5 \mathrm{~min}$ at $1500 \mathrm{~g}$. Samples were stored at $-50^{\circ} \mathrm{C}$ for not longer than 1 month before analysis. For extracting the internal nutrient pools, $10 \mathrm{ml}$ of culture was centrifuged for $10 \mathrm{~min}$ at $1500 \mathrm{~g}$. After careful removal of the supernatant, the pellet was extracted in $3 \mathrm{ml}$ of demineralized water $\left(18.2 \mathrm{M} \Omega \mathrm{cm}^{-1}\right)$ for $2 \mathrm{~min}$ at $100^{\circ} \mathrm{C}$. The extract was centrifuged again for $3 \mathrm{~min}$ at $1500 \mathrm{~g}$ and $2.5 \mathrm{ml}$ of the supernatant was carefully removed and stored at $-50^{\circ} \mathrm{C}$ until analysis. Nutrient analyses were carried out using the method described by Grasshoff \& Erhardt (1983). Cells were counted using an inverted microscope on $250 \mu \mathrm{l}$ samples in a microtitre plate.

The uptake rates were estimated using a linear regression on the initial decrease in the external nutrient concentration. The data points before nutrient concentration dropped below $2 \mu \mathrm{mol} \mathrm{l}^{-1}$ were used and gave significant regressions, except for the uptake experiments in the dark. The specific uptake rate was calculated using the concentration of particulate nitrogen present at the start of a new $3 \mathrm{~d}$ interval, just after dilution. On theoretical grounds, when all the supplied nitrogen from the previous $3 \mathrm{~d}$ interval is converted into biomass the particulate nitrogen concentration is $10 \mu \mathrm{mol} \mathrm{N} \mathrm{l}^{-1}$.

\section{RESULTS}

The estimated initial uptake rates of all experiments are summarized in Table 1.

\section{D. brightwellii}

Nitrate-pulsed cells. The mean cell volumes of the different D. brightwellii strains were $130000 \mu \mathrm{m}^{3}$ (large and $35000 \mu \mathrm{m}^{3}$ (small) in the nitrate-pulsed culture. Nitrate concentration in the external medium showed a rapid decrease with time (Fig. 1a, b). During the first $5 \mathrm{~h}$, nitrate uptake rates (Table 1 ) of the large- and small-celled cultures did not differ significantly $(P=0.45 ; n=8)$. Mean biomass (cell nitrogen) specific uptake rates were $0.23 \mathrm{~d}^{-1}$. After $5 \mathrm{~h}$, the nitrate uptake remained unaffected in the large-cell culture, whereas the small-cell culture showed a slight decrease in nitrate uptake. In the culture with the larger cells, the highest intracellular nitrate pool was $6.33 \mu \mathrm{mol}(1 \text { culture })^{-1}$. This corresponds to a concentration of $21 \mathrm{mM}$ assuming that the internal pool is evenly distributed over the total cell volume. The culture with the smaller cells had a lower maximum intracellular nitrate pool $\left[4.14 \mu \mathrm{mol}(1 \text { culture })^{-1}\right]$, but the calculated intracellular concentration was higher $(26 \mathrm{mM})$ than in the large cell culture. The inorganic nitrogen which was taken up was converted into biomass in $3 \mathrm{~d}$. This caused a doubling of cell number over the $3 \mathrm{~d}$ period (data not shown).

Ammonium-pulsed cells. The ammonium-grown $D$. brightwellii cultures were started two weeks later than the nitrate-grown cultures, and mean cell volumes were therefore lower: $100000 \mu^{3}$ (large) and $30000 \mu \mathrm{m}^{3}$ (small). External ammonium was taken up rapidly by the cells in both cultures and was below the detection level within $5 \mathrm{~h}$ (Fig. 2a, b). The initial biomass-specific uptake rates (Table 1) of the small- and large-celled cultures differed significantly $(P=0 \cdot 009)$. Uptake rate was higher for the smaller cells $\left(0.29 \mathrm{~h}^{-1}\right)$ than for the larger cells $\left(0.20 \mathrm{~h}^{-1}\right)$. No increased pools of internal ammonium were detected after the pulse. Similar to the nitrate cultures, the cell number increased by a factor two over the $3 \mathrm{~d}$ (not shown).

Nitrate-pulsed cells in the dark. The effect of cell size on nitrate uptake in the dark was then studied. Because the linear part of the decrease of the nitrate concentration was covered by too few data points, the initial uptake rate was not estimated using linear regression. However, the uptake rate of nitrate in the dark was slower than in the 
Table 1. Initial nitrate and ammonium uptake rates by different cultures in the light

Uptake rates are calculated as slopes of the external nutrient concentration versus time relationship after a pulse, using linear regression (standard error of the slope in parentheses). Specific nitrate and ammonium uptake rates were calculated as $\mu \mathrm{mol}$ nitrogen taken up per $\mu \mathrm{mol}$ cell nitrogen at $t=0$ per hour.

\begin{tabular}{|c|c|c|c|c|c|}
\hline \multirow[t]{2}{*}{ Species } & \multirow{2}{*}{$\begin{array}{c}\text { Cell } \\
\text { volume } \\
\left(\mu \mathrm{m}^{3}\right)\end{array}$} & \multicolumn{2}{|c|}{$\begin{array}{c}\text { Uptake rate } \\
\left(\mu \mathrm{mol} 1^{-1} h^{-1}\right) \text { of: }\end{array}$} & \multicolumn{2}{|c|}{$\begin{array}{l}\text { Specific uptake } \\
\left(h^{-1}\right) \text { of: }\end{array}$} \\
\hline & & Nitrate & Ammonium & Nitrate & Ammonium \\
\hline$T$. pseudonana & 98 & $0.97(0.05)$ & $1 \cdot 36(0 \cdot 18)$ & 0.097 & $0 \cdot 14$ \\
\hline L. borealis & 7474 & $1.85(0 \cdot 14)$ & $0.96(0.09)$ & 0.19 & 0.096 \\
\hline D. brightwellii & 30000 & & $2.90(0.09)$ & & 0.29 \\
\hline D. brightwellii & 35000 & $2 \cdot 12(0 \cdot 30)$ & & $0 \cdot 21$ & \\
\hline D. brightwellii & 100000 & & $2.03(0 \cdot 16)$ & & 0.20 \\
\hline D. brightwellii & 130000 & $2.47(0.29)$ & & $0 \cdot 25$ & \\
\hline
\end{tabular}

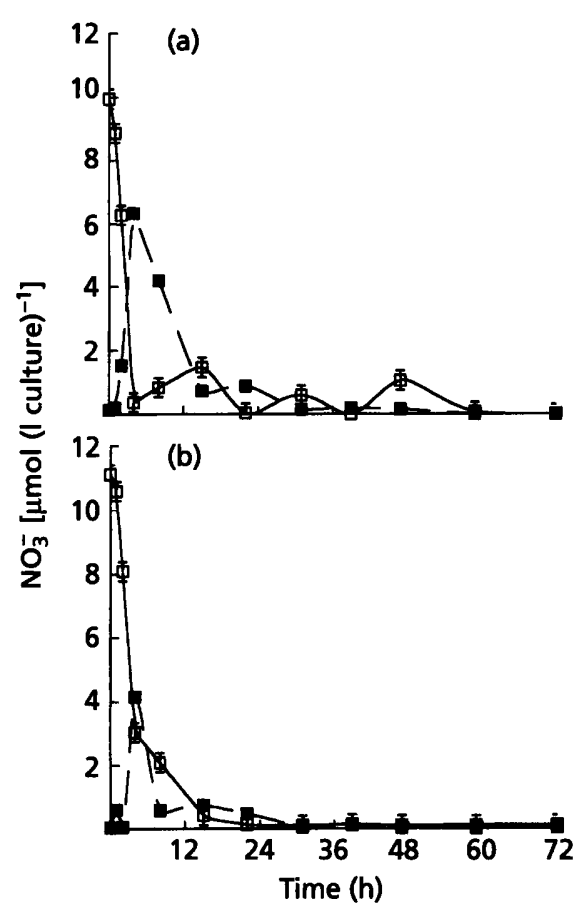

Fig. 1. Extracellular $(\square)$ and intracellular $(\square)$ concentrations of nitrate in a culture of $D$. brightwellii after addition of $10 \mu \mathrm{M}$ nitrate at $t=0$ in the light. (a) Culture with mean single-cell volume of $130000 \mathrm{\mu m}^{3}$; (b) culture with mean single-cell volume of $35000 \mu^{3}$. In this and other Figures, the error bars represent the maximum absolute error in the determination of the concentration of the particular nutrient.

light. In both cultures, uptake took place in two phases (Fig. 3a, b). The smaller cells had a very short period of rapid initial uptake rate and then continued taking up nitrate at a slower rate. The larger cells had a prolonged period of relatively high initial uptake rate. Intracellular pools of nitrate were lower than in the light and showed some fluctuations with time. The maximum pools of nitrate were $5 \mu \mathrm{mol}(1 \text { culture })^{-1}$ for the largest cells and

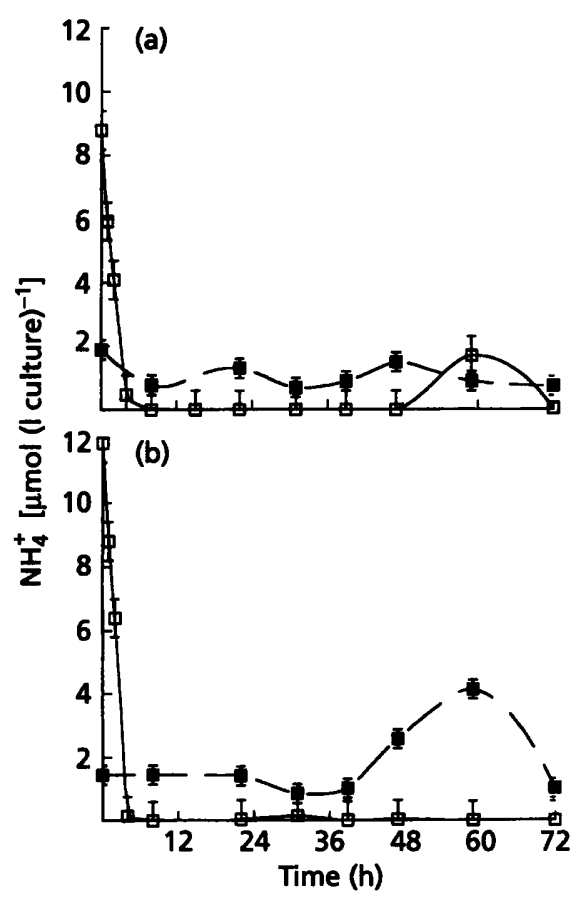

Fig. 2. Extracellular $(\square)$ and intracellular $(\square)$ concentrations of ammonium in a culture of $D$. brightwellii after addition of $10 \mu \mathrm{M}$ ammonium at $t=0$ in the light. (a) Culture with mean single-cell volume of $100000 \mu \mathrm{m}^{3}$; (b) culture with mean singlecell volume of $30000 \mu^{3}$.

about $3 \mu \mathrm{mol}(1 \text { culture })^{-1}$ for the smaller cells. The internal pools were not depleted completely during the experiment.

\section{L. borealis and $T$. pseudonana}

In the previous experiments, the size-dependent uptake within one species was studied. To see if the results could be applied to other species, nitrate and ammonium uptake 


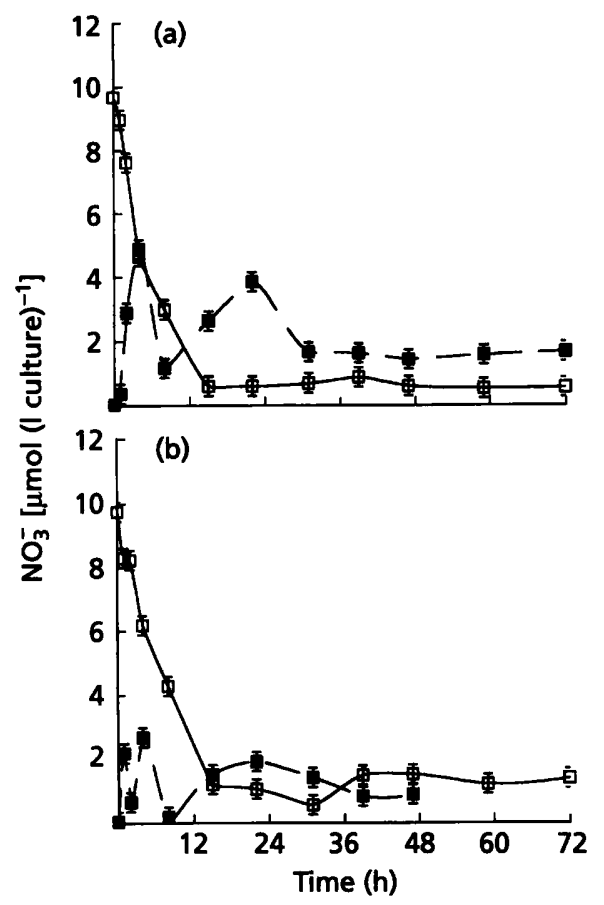

Fig. 3. Extracellular $(\square)$ and intracellular $(\square)$ concentrations of nitrate in a culture of $D$. brightwellii after addition of $10 \mu \mathrm{M}$ nitrate at $t=0$ in the dark. (a) Culture with mean single-cell volume of $130000 \mathrm{\mu m}^{3}$; (b) culture with mean single-cell volume of $35000 \mu \mathrm{m}^{3}$.

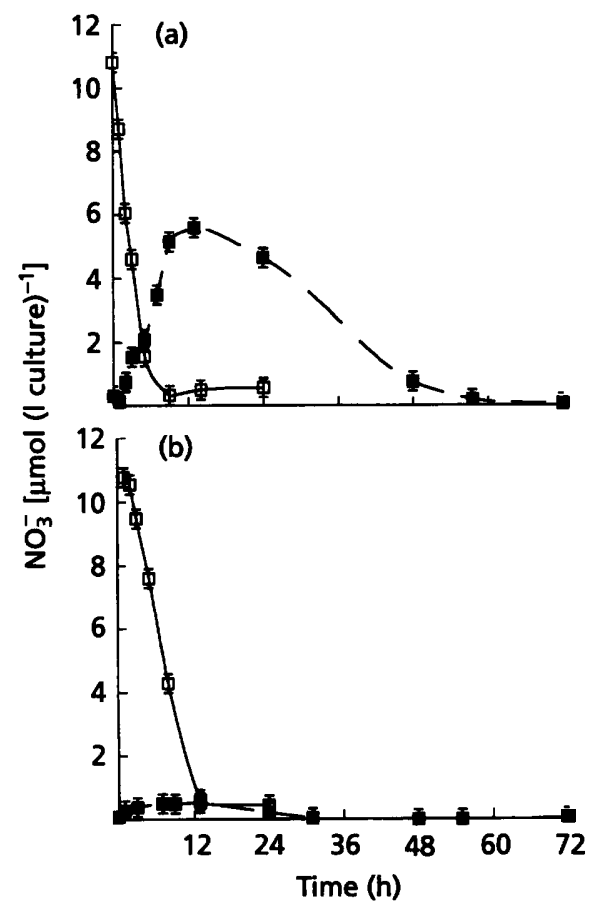

Fig. 4. Extracellular $(\square)$ and intracellular $(\square)$ concentrations of nitrate after addition of $10 \mu \mathrm{M}$ nitrate at $t=0$ in the light. (a) L. borealis $\left(7474 \mu \mathrm{m}^{3}\right)$; (b) T. pseudonana $\left(98 \mu \mathrm{m}^{3}\right)$.

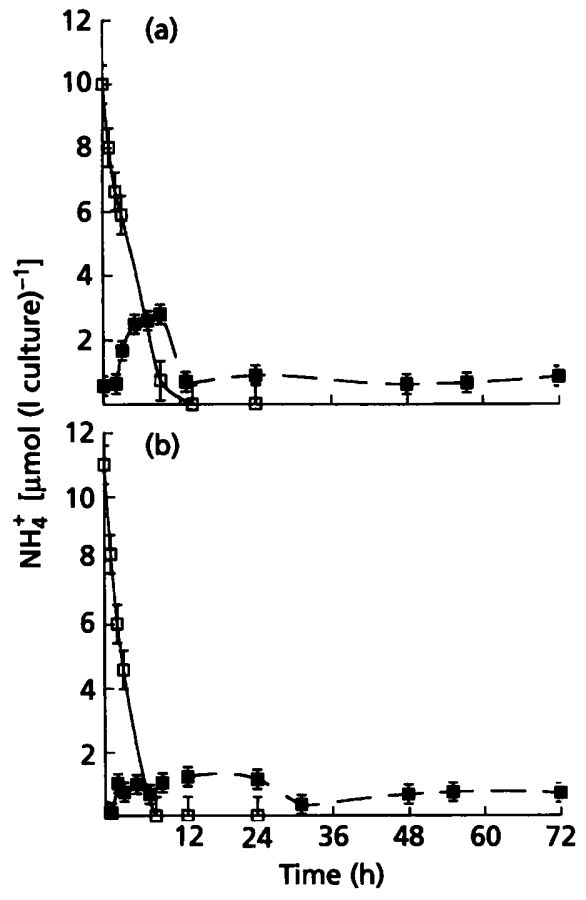

Fig. 5. Extracellular $(\square)$ and intracellular $(\square)$ concentrations of ammonium after addition of $10 \mu \mathrm{M}$ ammonium at $t=0$ in the light. (a) L. borealis $\left(7474 \mu \mathrm{m}^{3}\right)$; (b) T. pseudonana $\left(98 \mu \mathrm{m}^{3}\right)$.

in a small $\left(98 \mu \mathrm{m}^{3}\right)$ and an intermediate $\left(7474 \mu \mathrm{m}^{3}\right)$ species was also determined in a third experiment.

Nitrate-pulsed cultures. The larger diatom $L$. borealis took up nitrate at a higher rate than T. pseudonana (Fig. 4a, b). Initial biomass-specific uptake rates of nitrate were $0.19 \mathrm{~h}^{-1}$ for $L$. borealis and $0.097 \mathrm{~h}^{-1}$ for $T$. pseudonana, compared to $0.23 \mathrm{~h}^{-1}$ for $D$. brightwellii in experiment 1 (Table 1). The internal pool of nitrate reached much higher values in the L. borealis culture than in the smallsized $T$. pseudonana culture. From the cells of $L$. borealis, more than $50 \%$ of the externally added nitrate was maximally recovered as internal nitrate. From the $T$. pseudonana culture, a maximum of $5 \%$ was recovered as internal nitrate. Internal and external ammonium and nitrite concentrations were below the detection level.

Ammonium-pulsed cultures. Ammonium was also rapidly taken up. T. pseudonana took up ammonium slightly, but not significantly, faster $(P=0 \cdot 10, n=10)$ than $L$. borealis (Fig. 5a, b). However, the uptake rates of both cultures were about half the rates of the $D$. brightwellii cultures. Internal ammonium pools were lower than in the case of nitrate, but highest in the L. borealis culture [max. $3 \mu \mathrm{mol}$ $(1 \text { culture })^{-1}$ ].

\section{DISCUSSION}

In the Theoretical Background section above, calculations were made on the steady-state or nutrient-balanced growth of algae. With the assumption that $V_{\max }$ was linearly related to the cell surface, this resulted in a 
theoretical size dependence of maximum specific growth rate:

$\mu_{\max }=\frac{\alpha}{a^{\prime}} . W^{b}$

Using the phosphorus content data of a large group of algae we derived a value of $b=-0 \cdot 10$ (eq. 7 ). When the nitrogen content of a group of five diatoms is considered, $b=-0 \cdot 20$ (eq. $7 \mathrm{a})$.

These values are in good agreement with values empirically derived by other investigators. Although Grover (1989b) did not find a significant relation between $\mu_{\max }$ and cell size in his experiments, other investigators found negative values for $b$; for low-temperature species, the relation is weaker $(b=-0.08$; Sommer, 1989), while for diatoms $(b=-0.14$; Blasco et al., 1982) and dinoflagellates $(b=-0 \cdot 15$; Chan, 1978) the size dependence of $\mu_{\max }$ is in the same range as we derived. Compared to a very large range of heterotrophic organisms $(b=-0.25$; Peters, 1983) and ciliates $(b=-0.25$; Banse, 1982) the size dependence of $\mu_{\max }$ is not strong for algae. The fact that, based on nutrient uptake, the relationship of $\mu_{\max }$ could be described very well, could suggest that algae, growing at their maximum growth rate, are primarily limited by the rate of nutrient assimilation.

We hypothesized that based on the surface to (nitrogen) biomass ratio no strong relationship between specific growth rate and size could be expected under steady-state nitrogen limitation (eq. 5). The assumptions we made were as follows. (a) $V_{\max }$ is linearly related to cell surface. The reason for assuming this is that algae can adapt their uptake capacity only to a certain extent, finally limited by the available surface area. However, it is likely that differences occur between taxonomic groups. (b) $K_{\mathrm{m}}$ is not dependent on cell size. In our view, $K_{\mathrm{m}}$ is only dependent on enzyme characteristics. It is understandable that enzyme types are related to taxonomic groups, but not that they are size related. Parsons \& Takahashi (1974), using the data of Eppley et al. (1969), found a positive correlation of $K_{\mathrm{m}}$ for ammonium and nitrate uptake with cell size. However, the observed concentration dependence of the uptake rate may not only be a result of the uptake at the cell surface, but also of the diffusion rate of the solute towards the cell. When the uptake rate is determined as a function of the bulk concentration, no distinction can be made between these two factors. The measured $V-S$ relationship may therefore not provide the true $K_{\mathrm{m}}$ value of the uptake system, but an apparent $K_{\mathrm{m}}$, determined by the uptake characteristics of the algae and the diffusion of nutrients to the cells. This might be a reason why $K_{\mathrm{m}}$ is found to be positively related to cell size.

The growth rate under steady-state nitrogen-limiting conditions is affected by the weak size dependence of the surface-to-biomass ratio. During a transient state, feedback inhibition of the uptake system plays an additional role.

\section{Nitrate uptake}

The hypothesis that cell size does not influence biomass specific initial nutrient uptake rates (eq. 8) was confirmed by the first experiment, in which the two cultures of $D$. brightwellii with a factor of four difference in cell volume had the same initial nitrate uptake rate. However, the large cells were capable of taking up nitrate at a maximum rate for a longer period than the small cells. For this reason, in the culture with the large $D$. brightwellii cells, nitrate was exhausted from the external medium in a shorter period of time than in the other culture. Also, in the large cell culture internal pools of nitrate were much higher, while the calculated intracellular concentration of nitrate was somewhat lower. This supports the hypothesis that larger cells have a larger storage volume relative to their biomass. In Fig. 1(a) the fluctuations in the internal and external pools of nitrate from 10 to around 40 may indicate that at that point there was some exchange of nitrate between the cells and the surrounding medium. At $t=48 \mathrm{~h}$, however, an increase of the total nitrate pool was observed. Probably this was caused by contamination of the sample with nitrate, since nitrate formation would not be expected to occur in an axenic culture of algae.

In the experiment in which nitrate uptake of the same $D$. brightwellii strains was measured in the dark, the size difference in uptake kinetics was even more pronounced. Internal nitrate pools were higher in the culture with the large cells. Coinciding with this, the disappearance of nitrate from the external medium was more rapid in this culture. The large fluctuations in the internal pools in both dark uptake experiments might have been a result of the limited availability of reduction equivalents, resulting in competition for reduction equivalents between ATP-generating and nitrate-reductive enzymes.

Although within the two cultures of $D$. brigbtwellii no difference in initial nitrate uptake was observed, the two smaller species tested in the third experiment took up nitrate at a lower rate. The smallest species ( $T$. pseudonana) took up nitrate at the lowest rate (Table 1). It has already been shown that the transient-state uptake rate of nitrate increased with cell size (Stolte et al., 1994). An explanation for this may be that net transport of nitrate over the cell membrane is reduced by a negative feedback system on a smaller time scale than that which we sampled (DeManche et al., 1979). In this case, the uptake rate we observed would not be the maximum uptake rate possible over the membrane, but rather the rate-limiting step for nitrate assimilation, most probably nitrate reduction. However, it is not possible to confirm this based on the data presented here.

\section{Ammonium uptake}

Although the initial biomass-specific ammonium uptake rate of the smaller $D$. brightwellii cells was significantly higher $(P=0.009)$ than that of the larger cells, this trend was not observed when the two other species were studied. Comparing the three different species, the uptake of ammonium was not related to cell size. In the $L$. borealis culture, the intracellular ammonium pool was elevated 
above the background level for several hours. However, the maximum pool was lower than the maximum nitrate pool with the same species. In both the $D$. brightwellii and the $T$. pseudonana cultures, internal ammonium pools were not elevated significantly. Only at the end of the $3 \mathrm{~d}$ period of the small $D$. brightwellii culture was a significant amount of internal ammonium detected. We can not explain this peak of intracellular ammonium in physiological terms. Because none of the other ammonium uptake experiments showed a similar pattern, it might have been an artifact formed during sampling or extraction. The reason that in most cultures no large ammonium pools were formed is because assimilation of ammonium is a faster process than the uptake from the external medium. It could also be that accumulation of ammonium is not possible because it diffuses across the cell membrane more easily than the negatively charged nitrate. Because a significant ammonium pool is observed in the L. borealis culture it is obvious, at least for this species, that it is possible to accumulate ammonium at higher concentrations. Therefore, we conclude that, although the efflux of ammonium by diffusion will be more significant than that of nitrate, it is most probable that ammonium is not accumulating in $D$. brightwellii because ammonium is much more rapidly incorporated in amino acids than it is taken up at the cell surface.

\section{General conclusions}

It has become clear during the last decade or so that marine ecosystems are not as homogeneous as was previously believed. Even in the oligotrophic areas of oceans, phytoplankton is confronted with variable light and nutrient concentrations. The capability of taking up temporarily elevated levels of a nutrient can be a strong selective factor in waters which are frequently enriched with nutrients (Turpin \& Harrison, 1979; Stolte et al., 1994). Because nitrogen has often been shown to control the primary production in coastal (Vince \& Valiela, 1973; Laws \& Redalje, 1979) and oceanic systems (Sharp et al., 1980), the present study focused on transient-state uptake of ammonium and nitrate. It is concluded that nitrate uptake is more related to phytoplankton cell size than is ammonium uptake. This is explained by the fact that ammonium is assimilated more rapidly than nitrate. The transient-state uptake of nitrate in $D$. brightwellii can be divided into two stages: an initial rate, probably limited by the transport at the cell surface; and a second stage with a lower rate, possibly limited by nitrate reduction in the cytoplasm. Depending on the frequency and amplitude of the fluctuations, storage of nitrate may be important to provide an efficient use of pulses of nitrate.

It has been suggested that iron deficiency can limit phytoplankton growth in certain parts of the oceans (Martin \& Fitzwater, 1988). A more detailed study reveals that nitrate reduction rather than nitrate uptake is stimulated after enrichment of natural phytoplankton assemblages with iron (Timmermans et al., 1994). The already rate-limiting step of nitrate reduction is in that case even more diminished. Therefore, in the theoretical case that iron-stressed phytoplankton is confronted with fluctuating concentrations of nitrate, storage of nitrate could even have a more size-selective effect, because the rate of nitrate reduction is at a lower level than in ironreplete algae.

In this paper we have presented evidence that large algae are better competitors for nitrate under fluctuating conditions, because of their larger specific storage volume. Theoretically, we have shown that this could be due to a relative increase in vacuole volume. Indeed in the experiments, maximum biomass-specific intracellular nitrate pools increased with cell size within the same strain. Although in our experiments only diatoms were involved, the theoretical considerations are based on algorithms which have been shown to be valid for all taxonomic groups. Therefore we conclude that fluctuating nutrient concentrations in natural waters could potentially favour the dominance of larger algal species if nitrate rather than ammonium is the main nitrogen source.

\section{ACKNOWLEDGEMENTS}

Karen Smith is gratefully acknowledged for her assistance with the experiments. We thank Dr Klaas Timmermans and Dr J. van der Meer for their critical comments on earlier drafts of the manuscript. Also, useful discussions with Dr Kevin Flynn are highly appreciated.

\section{REFERENCES}

Banse, K. (1976). Rates of growth, respiration and photosynthesis of unicellular algae as related to cell size - a review. J Pbycol 12, 135-140.

Banse, K. (1982). Cell volumes, maximal growth rates of unicellular algae and ciliates, and the role of ciliates in the marine pelagial. Limnol Oceanogr 27, 1059-1071.

Blasco, D., Packard, T. T. \& Garfield, P. C. (1982). Size dependence of growth rate, respiratory electron transport system activity and chemical composition of marine diatoms in the laboratory. $J$ Phycol 18, 58-63.

Chan, A. T. (1978). Comparative physiological study of marine diatoms and dinoflagellates in relation to irradiance and cell size. 1 . Growth under continuous light. J Pbycol 14, 396-402.

DeManche, J. M., Curl, H. C., Jr, Lundy, D. W. \& Donaghay, P. L. (1979). The rapid response of the marine diatom Skeletonema costatum to changes in external and internal nutrient concentration. Mar Biol 53, 323-333.

Dortch, Q. (1982). Effect of growth conditions on accumulation of internal nitrate, ammonium, amino acids, and protein in three marine diatoms. J Exp Mar Biol Ecol 61, 243-264.

Eppley, R. W., Rogers, J. N. \& McCarthy, J. J. (1969). Halfsaturation constants for uptake of nitrate and ammonium by marine phytoplankton. Limnol Oceanogr 14, 912-920.

Grasshoff, K. \& Ehrhardt, M. (1983). Automated chemical analysis. In Metbods of Seawater Analysis, 2nd edn, pp. 263-289. Edited by K. Grasshoff, M. Ehrhardt \& K. Kremling. Weinheim: Verlag Chemie.

Grover, J. P. (1989a). Influence of cell shape and size on algal competitive ability. J Phycol 25, 402-405.

Grover, J. P. (1989b). Phosphorus-dependent growth kinetics of 11 species of freshwater algae. Limnol Oceanogr 34, 341-348. 
Hobbie, J. E., Daley, R. J. \& Jasper, S. (1977). Use of Nuclepore filters for counting bacteria by fluorescence microscopy. Appl Environ Microbiol 33, 1225-1228.

Laws, E. A. \& Redalje, D. G. (1979). Effect of sewage enrichment on the phytoplankton population of a subtropical estuary. Pac Sci 33, 129-144.

Margalef, R. (1978). Life-forms of phytoplankton as survival alternatives in an unstable environment. Oceanol Acta 1, 493-509.

Martin, J. H. \& Fitzwater, S. E. (1988). Iron deficiency limits phytoplankton growth in the northeast Pacific subarctic. Nature 331, 341-343.

Miller, A. J. \& Zhen, R.-G. (1991). Measurement of intracellular nitrate concentrations in Chara using nitrate-selective microelectrodes. Planta 184, 47-52.

Munk, W. H. \& Riley, G. A. (1952). Absorption of nutrients by aquatic plants. $J$ Mar Res 11, 215-240.

Owens, N. J. P., Woodward, E. M. S., Aiken, J., Bellan, I. E. \& Rees, A. P. (1990). Primary production and nitrogen assimilation in the North Sea during July 1987. Neth J Sea Res 25, 143-154.

Owens, N. J. P., Priddle, J. \& Whitehouse, M. J. (1991). Variations in phytoplanktonic nitrogen assimilation around South Georgia and in the Bransfield Strait (Southern Ocean). Mar Chem 35, 287-304.

Parsons, T. R. \& Takahashi, M. (1973). Environmental control of phytoplankton cell size. Limnol Oceanogr 18, 511-515.

Parsons, T. R. \& Takahashi, M. (1974). A rebuttal to the comment by Hecky and Kilham. Limnol Oceanogr 19, 366-368.

Pasciak, W. J. \& Gavis, J. (1974). Transport limitation of nutrient uptake in phytoplankton. Limnol Oceanogr 19, 881-888.

Peters, R. H. (1983). The Ecological Implications of Body Size (Cambridge Studies in Ecology 2). Cambridge: Cambridge University Press.

Price, N. M., Andersen, L. G. \& Morel, F. M. M. (1991). Iron and nitrogen nutrition of equatorial Pacific plankton. Deep-Sea Res 38, 1361-1378.

Probyn, T. A. (1985). Nitrogen uptake by size-fractionated phytoplankton populations in the southern Benguela upwelling system. Mar Ecol Progr Ser 22, 249-258.

Raven, J. A. (1984). Energetics and Transport in Aquatic Plants (MBL Lectures in Biology 4). New York: Alan R. Liss.
Raven, J. A. (1986). Physiological consequences of extremely small size for autotrophic organisms in the sea. In Pbotosynthetic Picoplankton. Edited by T. Platt \& W. K. W. Li. Can Bull Fish Aquat Sci 214, 1-70.

Riegman, R., Kuipers, B. R., Noordeloos, A. A. M. \& Witte, H. J. (1993). Size differential control of phytoplankton and the structure of plankton communities. Neth J Sea Res 31, 255-265.

Sharp, J. H., Perry, M. J., Renger, E. H. \& Eppley, R. W. (1980). Phytoplankton rate processes in the oligotrophic waters of the central North Pacific Ocean. J Plankton Res 2, 335-353.

Shuter, B. J. (1978). Size dependence of phosphorus and nitrogen subsistence quotas in unicellular microorganisms. Limnol Oceanogr 23, 1248-1255.

Smith, R. E. H. \& Kalff, J. (1982). Size-dependent phosphorus uptake kinetics and cell quota in phytoplankton. $J$ Pbycol 18, 275-284.

Sommer, U. (1989). Maximal growth rates of antarctic phytoplankton: only weak dependence on cell size. Limnol Oceanogr 34, 1109-1112.

Stolte, W., McCollin, T., Noordeloos, A. A. M. \& Riegman, R. (1994). Effect of nitrogen source on the size distribution within marine phytoplankton populations. J Exp Mar Biol Ecol 184, 83-97.

Timmermans, K. R., Stolte, W. \& De Baar, H. J. W. (1994). Iron mediated effects on nitrate reductase in marine phytoplankton. Mar Biol 121, 389-396.

Turpin, D. H. \& Harrison, P. J. (1979). Limiting nutrient patchiness and its role in phytoplankton ecology. J Exp Mar Biol Ecol 39, 151-166.

Veldhuis, M. J.W. \& Admiraal, W. (1987). The influence of phosphate depletion on the growth and colony formation of Phaeocystis pouchetii (Hariot) Lagerheim. Mar Biol 95, 47-54.

Vince, S. \& Valiela, I. (1973). The effects of ammonium and phosphate enrichments on chlorophyll $a$, pigment ratio and species composition of phytoplankton of Vineyard Sound. Mar Biol 19, 69-73.

Received 25 July 1994; revised 6 December 1994; accepted 10 January 1995. 